\title{
DIFFERENCES OF CONSUMER BEHAVIOUR REGARDING PLASTIC USAGE
}

\author{
Laima Jesevičiūtè-Ufartienè \\ Professor, PhD., Vilnius Gediminas Technical University \\ Sauletekio al. 11, 10223 Vilnius, Lithuania. \\ Tel +370 5 2744875, E-mail laima.jeseviciute-ufartiene@vgtu.lt
}

Received 1611 2019; accepted 20122019

The growth of plastic packaging waste and the need to manage it determine the relevance of this research. The problem is the lack of information about consumers' behavior regarding usage and wastage of plastic packaging in certain groups according to age, gender, incomes, and education in Lithuania. The purpose of the research is to investigate consumer behavior in the purchase process regarding the choice of plastic usage. Quantitative sampling was used to gather data from 641 respondent - consumers who regularly are shopping at the grocery stores for food. The research results revealed statistically significant differences in consumer behavior in the purchase process regarding the choice of plastic usage among gender, age, education level, and incomes.

The keywords: age, education, gender, incomes, plastic packaging, purchase, wasting.

JEL codes: D12, P46, Q53.

\section{Introduction}

Fighting with plastic waste amounts is becoming the biggest problem of the globe (Heidbreder et al., 2019). 40 percent of whole plastic production is plastic bags and packaging (Plastic waste, 2018). Less than a third of plastic waste in Europe is recycled and Lithuanians are among those who are the least recycling plastic (Plastic waste, 2018). Although CO2 of food packaging waste is 30 less than CO2 of food waste (Djekic et al., 2019), the food packaging waste is announced as a huge problem (Plastic waste, 2018; Heidbreder et al., 2019). The research (Schanes et al. 2018) showed growing numbers of purchasing amounts and waste. The most dangerous waste becomes the various types' plastic shopping bags and packaging of products (EC statement, 2019). Plastic and even eco plastic remains in Earth's top layers and pollutes the land and the water (Heidbreder et al., 2019). EU Plastics Strategy committed fighting with all plastic packaging on the EU market, making them reusable or recyclable by 2030 (EC statement, 2019). Therefore, several years are still ahead and people as customers could develop in their minds refusing to use plastic more rapidly.

According to research, consumers prefer to use plastic packaging because of their cheapness or free-distribution (Madara et al., 2016).

Copyright ( $) 2019$ The Authors. Published by Vytautas Magnus University. This is an open-access article distributed under the terms of the Creative Commons Attribution-NonCommercial 4.0 (CC BY-NC 4.0) license, which permits unrestricted use, distribution, and reproduction in any medium, provided the original author and source are credited. The material cannot be used for commercial purposes. 


\section{Differences of Consumer Behaviour Regarding Plastic Usage \\ Laima Jesevičiūtè-Ufartienè}

At the same time indication of differences among consumers diverge, thus, Heidbreder et al. (2019) recommend checking on demographic and social differences in every separate study.

The problem is that some information is provided to consumers about the harm of plastic because they perceive the risk of plastic usage (Syberg et al., 2018). However, it is not clear how much this information touches consumers' behavior in the purchase process and which groups of consumers are more responsible concerning pollution with the plastic. The research object is consumer behavior using plastic.

The purpose of this research is to investigate consumer behavior in the purchase process regarding the choice of plastic usage.

The benefits of the research to studies, science and / or business. The research value is its practical implications. Research results indicated differences among consumer groups. Thus, this research provides useful information for institutions developing interventions while fighting with plastic waste in Lithuania as specific educational programs should be applied to curtain consumers' segments getting the best results in the waste reduction process. Therefore, it should be mentioned that the research is narrow and shows a specific attitude to plastic waste, but it gives an overview of the existing need for future research for the management of plastic waste.

\section{Research methods}

Quantitative sampling was used to gather data for the research. Research respondents were taken consumers who regularly are shopping at the grocery stores for food. Thus, all Lithuanian grownups were included in the research population. The sample size of 385 respondents was calculated according to 2,808,901 population in Lithuania (Statistics, 2018), 95\% confidence level, $5 \%$ of error level and $50 \%$ of response distribution (Raosoft, 2019). The research was taken in November of 2018. There were conducted 641 respondents inertly.

Data of the research were analyzed using descriptive statistics, measuring frequencies and mean values of analyzed scales which were formed using Likert scale from 1 to 5, with the meanings: 1 means 'totally disagree', 2 'disagree', 3 'partly agree', 4 'agree' and 5 'totally agree'. Demographic data such as gender, age, incomes, and education served as factors for group division. The author applied the nonparametric test of Mann-Whitney U for gender analyses. She applied the nonparametric test of Kruskal-Wallis $\mathrm{H}$ for age, education level, and incomes. The difference between demographically divided groups was significant when $\mathrm{p}<0.05$. Data were analyzed using the SPSS program.

\section{Results and discussion}

Data in table 1 reveal slight differences in mean values among research items. It could be stated that Lithuanian people rarely use the same bag or own bag for shopping. Although, they show intention for checking if the packaging of the product could be recycled or choosing to use reusable packaging. However, the value of the standard deviation of mean values in table 1 cautions that replies of respondents have great distribution and the deeper analyses must be explored which could be found hereafter. 


\section{Management Theory and Studies for Rural Business and Infrastructure Development eISSN 2345-0355. 2019. Vol. 41. No. 4: 520-526 \\ Article DOI: https://doi.org/10.15544/mts.2019.42}

Table1. Mean value of analysed scales regarding packaging usage

\begin{tabular}{|c|c|c|}
\hline Scales of Questions & Mean & Std. Deviation \\
\hline Usage of the same bag at least twice & 2.34 & 1.318 \\
\hline Using own bag for shopping & 2.84 & 1.360 \\
\hline Usage of reusable coffee cup more than disposable & 3.05 & 1.428 \\
\hline Buying products in the plastic packaging & 3.06 & 1.188 \\
\hline Buying of plastic bag & 3.12 & 1.292 \\
\hline Choosing to use reusable packaging & 3.26 & 1.227 \\
\hline Choosing to buy eco-plastic bag while shopping & 3.54 & 1.332 \\
\hline Checking if the packaging of the product could be recycled & 3.59 & 1.247 \\
\hline
\end{tabular}

Whereas Hohmann et al. (2016) found differences in plastic bag usage between women and men, it was interesting to make data cut in this direction. Subsequent to the analysis of the data in table 2 reveal statistically significant gender differences among several scales. It shows that men more frequently than women are using own bag for shopping or use the same bag at least twice for shopping. These results are opposite to Madigele et al. (2017) research results where women showed greater intention than men for the usage of alternatives of plastic bags. Thus, presumption could be that differences among gender exists in different countries and further research should include cultural aspects.

Table 2. Differences in consumption of plastic packaging related to gender

\begin{tabular}{|l|c|c|c|r|r|r|}
\hline & Gender & Female & Male & \multicolumn{4}{|c|}{ Mann-Whitney Test } \\
\cline { 4 - 7 } Scales of Questions & 413 & 228 & $\mathbf{U}$ & $\mathbf{W}$ & $\mathbf{Z}$ & $\begin{array}{r}\text { Asymp. Sig. } \\
\text { (2-tailed) }\end{array}$ \\
\hline Using own bag for shopping & & & & & & $\mathbf{0 . 0 0 0}$ \\
\hline Usage of the same bag at least twice & 280.58 & 357.99 & 38648.500 & 124139.500 & -3.841 & $\mathbf{0 . 0 0 0}$ \\
\hline Buying of plastic bag & 328.58 & 377.37 & 34229.000 & 119720.000 & -5.911 & 0.152 \\
\hline $\begin{array}{l}\text { Usage of reusable coffee cup more than } \\
\text { disposable }\end{array}$ & 313.24 & 335.06 & 43876.500 & 129367.500 & -1.457 & 0.145 \\
\hline Buying products in the plastic packaging & 324.55 & 314.57 & 45616.500 & 71722.500 & -0.676 & 0.499 \\
\hline $\begin{array}{l}\text { Choosing to buy eco-plastic bag while } \\
\text { shopping }\end{array}$ & 319.11 & 324.43 & 46300.500 & 131791.500 & -0.359 & 0.720 \\
\hline $\begin{array}{l}\text { Checking if the packaging of the product } \\
\text { could be recycled }\end{array}$ & 322.35 & 318.56 & 46526.500 & 72632.500 & -0.256 & 0.798 \\
\hline Choosing to use reusable packaging & 321.98 & 319.23 & 46679.000 & 72785.000 & -0.185 & 0.853 \\
\hline Note: the difference is significant if p < 0.05 & & & & \\
\hline
\end{tabular}

Afroz et al. (2017) revealed that older people show more intentions to fight the usage of plastic bags than younger ones. Though, Elgaaïed-Gambier (2016) results are opposite to Afroz et al. (2017). Elgaaïed-Gambier (2016) research data is consistent with research data in table 3 where young independent people aged 23-30 declare buying the plastic bag less than very young aged 16-22 or old people 66 and more.

The statistically significant differences in table 3 reveal that very young people aged 1622 are more frequently using their bag for shopping than older people aged 66 and more. 


\section{Differences of Consumer Behaviour Regarding Plastic Usage \\ Laima Jesevičiūté-Ufartienè}

Although, it is known that eco plastic is even more harmful to the green world and humans, very young and older than 66 show more intention of buying eco-plastic bag than people aged 23-50. The author's presumption is that very young aged 16-22 and old people aged 66 and more are less informed about the harm of eco-plastic and at the same time it is a sensitive group that should be taken in mind preparing and working on preventive programs fighting with the growth of plastic.

Table 3. Differences in consumption of plastic packaging related to age

\begin{tabular}{|l|c|c|c|c|c|c|r|r|}
\hline \multicolumn{1}{|c|}{ Age range } & $\mathbf{1 6 - 1 8}$ & $\mathbf{1 9 - 2 2}$ & $\mathbf{2 3 - 3 0}$ & $\mathbf{3 1 - 5 0}$ & $\mathbf{5 1 - 6 5}$ & $\begin{array}{c}\mathbf{6 6} \text { and } \\
\text { more }\end{array}$ & \multicolumn{2}{c|}{$\begin{array}{c}\text { Kruskal-Wallis } \\
\text { Test }\end{array}$} \\
\cline { 2 - 9 } Scales of Questions & 43 & 230 & 137 & 136 & 63 & 27 & $\begin{array}{c}\text { Chi- } \\
\text { Square }\end{array}$ & $\begin{array}{c}\text { Asymp. } \\
\text { Sig. (p) }\end{array}$ \\
\hline Buying of plastic bag & 326.06 & 337.73 & 277.26 & 297.67 & 313.48 & 468.56 & 30.896 & $\mathbf{0 . 0 0 0}$ \\
\hline $\begin{array}{l}\text { Using own bag for } \\
\text { shopping }\end{array}$ & 362.24 & 357.85 & 330.28 & 304.67 & 221.80 & 149.19 & 57.212 & $\mathbf{0 . 0 0 0}$ \\
\hline $\begin{array}{l}\text { Usage of reusable coffee } \\
\text { cup more than disposable }\end{array}$ & 371.62 & 317.99 & 311.38 & 316.35 & 236.84 & 475.76 & 37.547 & $\mathbf{0 . 0 0 0}$ \\
\hline $\begin{array}{l}\text { Usage of the same bag at } \\
\text { least twice }\end{array}$ & 367.06 & 312.65 & 345.21 & 316.10 & 282.67 & 251.19 & 12.986 & $\mathbf{0 . 0 2 4}$ \\
\hline $\begin{array}{l}\text { Buying products in the } \\
\text { plastic packaging }\end{array}$ & 272.65 & 332.37 & 300.22 & 327.98 & 335.14 & 279.57 & 7.988 & .157 \\
\hline $\begin{array}{l}\text { Choosing to buy eco-plastic } \\
\text { bag while shopping }\end{array}$ & 352.33 & 344.39 & 290.98 & 289.60 & 270.44 & 441.41 & 30.678 & $\mathbf{0 . 0 0 0}$ \\
\hline $\begin{array}{l}\text { Checking if the packaging } \\
\text { of the product could be } \\
\text { recycled }\end{array}$ & 360.34 & 329.39 & 296.43 & 307.33 & 296.20 & 379.31 & 10.053 & 0.074 \\
\hline $\begin{array}{l}\text { Choosing to use reusable } \\
\text { packaging }\end{array}$ & 327.66 & 326.28 & 280.07 & 336.56 & 286.67 & 415.91 & 18.437 & $\mathbf{0 . 0 0 2}$ \\
\hline Note: the difference is significant if p $\mathrm{p} 0.05$ & & & & & \\
\hline
\end{tabular}

Another interesting and important aspect is the education aspect. Subsequent to the analysis of the data in table 4 reveal a statistically significant difference among the education of respondents. It shows that using own bag while shopping is more common to people with basic and secondary education. Furthermore, people with basic and secondary education are choosing to buy an eco-plastic bag while shopping.

These data direct to the same presumption that lack of information for certain groups about harm of eco-plastic exists. Though, it is strange that people with university education do not show much care about reusability of packaging while shopping which is opposite to people with basic or secondary education.

Furthermore, the revealed data in the table 4 is opposite to Madigele et al. (2017) and Afroz et al. (2017) research results were less educated people showed greater intention for plastic bag usage than higher education people or avoidance of disposable plastic packaging (JeżewskaZychowicz, Jeznach, 2015). Thus, presumption could be made about the need for deeper research, analyzing social desirability reasons for such differences among education group. This kind of research could be additional help forming plastic reduction programs in Lithuania. 
Table 4. Differences in consumption of plastic packaging related to education

\begin{tabular}{|c|c|c|c|c|c|c|}
\hline \multirow[b]{2}{*}{ Scales of Questions } & \multirow{2}{*}{$\begin{array}{c}\text { Basic } \\
37\end{array}$} & \multirow{2}{*}{$\begin{array}{c}\text { Secondary } \\
268\end{array}$} & \multirow{2}{*}{$\begin{array}{c}\text { Higher } \\
181\end{array}$} & \multirow{2}{*}{$\begin{array}{c}\text { University } \\
146\end{array}$} & \multicolumn{2}{|c|}{$\begin{array}{l}\text { Kruskal-Wallis } \\
\text { Test }\end{array}$} \\
\hline & & & & & $\begin{array}{c}\text { Chi- } \\
\text { Square }\end{array}$ & $\begin{array}{l}\text { Asymp. } \\
\text { Sig. (p) }\end{array}$ \\
\hline Buying of plastic bag & 357.45 & 322.51 & 309.21 & 304.14 & 3.282 & 0.350 \\
\hline Using own bag for shopping & 353.20 & 334.27 & 282.88 & 316.26 & 10.646 & 0.014 \\
\hline $\begin{array}{l}\text { Usage of reusable coffee cup more } \\
\text { than disposable }\end{array}$ & 341.09 & 324.63 & 298.47 & 317.71 & 3.100 & 0.377 \\
\hline Usage of the same bag at least twice & 376.30 & 322.71 & 309.05 & 299.19 & 6.285 & 0.099 \\
\hline $\begin{array}{l}\text { Buying products in the plastic } \\
\text { packaging }\end{array}$ & 297.99 & 324.79 & 310.07 & 313.94 & 1.275 & 0.735 \\
\hline $\begin{array}{l}\text { Choosing to buy eco-plastic bag while } \\
\text { shopping }\end{array}$ & 397.99 & 335.88 & 303.25 & 276.70 & 19.460 & 0.000 \\
\hline $\begin{array}{l}\text { Checking if the packaging of the } \\
\text { product could be recycled }\end{array}$ & 371.62 & 329.92 & 307.05 & 289.62 & 9.064 & 0.028 \\
\hline Choosing to use reusable packaging & 349.04 & 328.79 & 309.43 & 294.47 & 5.105 & 0.164 \\
\hline
\end{tabular}

Subsequent to the analysis of the data in table 5 statistically significant differences indicated among a certain range of incomes. This kind of analysis was not detected in previous studies. Three groups of respondents were determined:

- those who get less than 400 Eur per month and could be identified as low incomes group and close to poverty class;

- those who get in the range from 401 to 800 Eur per month, and could be identified as closer to the middle class;

- those who get more than 800 Eur per month and could be identified as middle class and the rich.

It is interesting to note that if higher education people are willing more to pay for a plastic bag, people with higher incomes are willing less to pay for a plastic bag (table 5). At the same time, richer people are using more their bag for shopping and less choosing to buy eco-plastic bags. Accordingly, two presumptions could be made.

Firstly, people with more incomes could be greater administrators of their incomes and more consciously using their money. Secondly, insufficient information about harm of plastic or eco-plastic in certain groups could be indicated in further research. 
Table 5. Differences in consumption of plastic packaging related to incomes

\begin{tabular}{|l|r|r|r|r|r|}
\hline \multirow{2}{*}{ Range of Incomes } & $\begin{array}{c}\text { Less than } \\
\mathbf{4 0 0}\end{array}$ & $\begin{array}{c}\mathbf{4 0 1 -} \\
\mathbf{8 0 0}\end{array}$ & $\begin{array}{c}\text { More than } \\
\mathbf{8 0 1}\end{array}$ & \multicolumn{2}{c|}{$\begin{array}{c}\text { Kruskal-Wallis } \\
\text { Test }\end{array}$} \\
\cline { 4 - 6 } Scales of Questions & 235 & 260 & 139 & $\begin{array}{c}\text { Chi- } \\
\text { Square }\end{array}$ & $\begin{array}{c}\text { Asymp. } \\
\text { Sig. }\end{array}$ \\
\hline Buying of plastic bag & 343.17 & 321.63 & 266.37 & 16.438 & $\mathbf{0 . 0 0 0}$ \\
\hline Using own bag for shopping & 314.59 & 301.58 & 352.20 & 7.335 & $\mathbf{0 . 0 2 6}$ \\
\hline Usage of reusable coffee cup more than disposable & 311.63 & 315.57 & 331.04 & 1.074 & 0.585 \\
\hline Usage of the same bag at least twice & 300.30 & 323.87 & 334.67 & 3.852 & 0.146 \\
\hline Buying products in the plastic packaging & 311.36 & 327.59 & 309.01 & 1.453 & 0.484 \\
\hline Choosing to buy eco-plastic bag while shopping & 350.92 & 304.54 & 285.23 & 14.296 & $\mathbf{0 . 0 0 1}$ \\
\hline $\begin{array}{l}\text { Checking if the packaging of the product could be } \\
\text { recycled }\end{array}$ & 327.14 & 318.43 & 299.47 & 2.145 & 0.342 \\
\hline Choosing to use reusable packaging & 319.89 & 322.07 & 304.91 & 0.915 & 0.633 \\
\hline Note: the difference is significant if p < 0.05 & & & & \\
\hline
\end{tabular}

\section{Conclusions}

The research results revealed statistically significant differences in consumer behavior in the purchase process regarding the choice of plastic usage. Lithuanian people rarely use the same bag or own bag for shopping but certain specificity among gender, age, education, and incomes was identified.

Gender analyses showed that men more frequently than women are using own bag for shopping or use the same bag at least twice for shopping. Age analyses among respondents' data revealed that very young people aged 16-22 are more frequently using their bag for shopping than older people aged 66 and more. As very young and older than 66 show more intention of buying eco-plastic bags than people aged 23-50 when it is known that eco plastic is even more harmful to the green world and humans. Thus, specific preventions programs should be applied to different age groups of people.

Higher education is not related to the higher consciousness of plastic consumption. People with basic and secondary education were more willing to use their bags for shopping. But it seems that people with basic and secondary education lack information about harm of ecoplastic. Thus, people with university education should be considered as a specific group. It could be specifically researched for the sociological and psychological reasons rejecting to fight with usage of plastic.

Incomes analyses among consumer behavior regarding plastic usage revealed that people with higher incomes are willing less to pay for plastic bag and are using more their bag for shopping and less choosing to buy eco-plastic bags than people with lower incomes. Accordingly, people with lower incomes must be informed using suitable advertising carrier assuring display and attention from this consumer's group. 


\section{Management Theory and Studies for Rural Business and Infrastructure Development eISSN 2345-0355. 2019. Vol. 41. No. 4: 520-526 \\ Article DOI: https://doi.org/10.15544/mts.2019.42}

\section{References}

Afroz, R., Rahman, A., Masud, M.M., Akhtar, R. (2017). The knowledge, awareness, attitude and motivational analysis of plastic waste and household perspective in Malaysia. // Environmental Science and Pollution Research. Vol. 24. No. 3. 2304-2315. - https://doi.org/ 10.1007/s11356-0167942-0. [2019 10 01]

Djekic, I., Miloradovic, Z., Djekic, S., Tomasevic, I. (2019). Household food waste in Serbia e Attitudes, quantities and global warming potential // Journal of Cleaner Production. Vol. 229. 44-52. http://doi.org/10.1016/j.jclepro.2019.04.400 [2019 10 01]

EC statement (2019). Circular Economy: Commission welcomes European Parliament adoption of new rules on single-use plastics to reduce marine litter. - https://europa.eu/rapid/pressrelease_STATEMENT-19-1873_en.htm [2019 10 21]

Elgaaïed-Gambier, L. (2016). Who buys overpackaged grocery products and why? Understanding consumers' reactions to overpackaging in the food sector. // Journal of Business Ethics. Vol. 135. No. 4. 683-698. - https://doi.org/10.1007/s10551-014-2491-2. [2019 10 01]

Heidbreder, L.M., Bablok, I., Drews, S., Menzel, C. (2019). Tackling the plastic problem: A review on perceptions, behaviors, and interventions // Science of the total environment. Vol. 668. 10771093. - https://doi.org/10.1016/j.scitotenv.2019.02.437 [2019 10 01]

Hohmann, R., Wattana, C., Sracheam, P., Siriapornsakul, S., Ruckthum, V., Clapp, R. (2016). An exploration of the factors concerned with reducing the use of plastic carrier bags in Bangkok, Thailand. // ABAC ODI Journal: Vision. Action. Outcome. Vol. 3. No. 2. 162-181.

Jeżewska-Zychowicz, M., Jeznach, M. (2015). Consumers' behaviours related to packaging and their attitudes towards environment. // Journal of Agribusiness and Rural Development. Vol. 3. No. 37. 447-457. - https://ideas.repec.org/a/ags/pojard/253597.html [2019 10 01]

Madara, D.S., Namango, S.S., Wetaka, C. (2016). Consumer-perception on polyethyleneshopping-bags // Journal of Environment and Earth Science. Vol. 6. No. 11. 12-36.

Madigele, P.K., Mogomotsi, G.E.J., Kolobe, M. (2017). Consumer willingness to pay for plastic bags levy and willingness to accept eco-friendly alternatives in Botswana // Chinese Journal of Population Resources and Environment. Vol. 15. No. 3. 255-261. - https://doi.org/ 10.1080/10042857.2017.1369243 [2019 10 01]

Plastic waste (2018). Plastic waste and recycling in the EU: facts and figures. https://www.europarl.europa.eu/news/en/headlines/society/20181212STO21610/plastic-waste-andrecycling-in-the-eu-facts-and-figures [2019-10-21]

Raosoft (2019). Sample size calculator. - http://www.raosoft.com/samplesize.html [2019 10 21].

Schanes, K., Dobernig, K., Gozet, B. (2018). Food waste matters - A systematic review of household food waste practices and their policy implications // Journal of cleaner production. Vol. 182. 978-991. - http://doi.org/10.1016/j.jclepro.2018.02.030 [2019 10 01]

Statistics (2018). - https:/eacea.ec.europa.eu/national-policies/eurydice/content/populationdemographic-situation-languages-and-religions-44_lt [2019 10 21].

Syberg, K., Hansen, S.F., Christensen, T.B., Khan, F.R. (2018). Risk perception of plastic pollution: importance of stakeholder involvement and citizen science // Wagner, M., Lambert, S. (Eds.), Handbook of Environmental Chemistry. Springer. Vol. 58. 203-221. -https://doi.org/10.1007/978-3319-61,615-5 [2019 10 01] 